
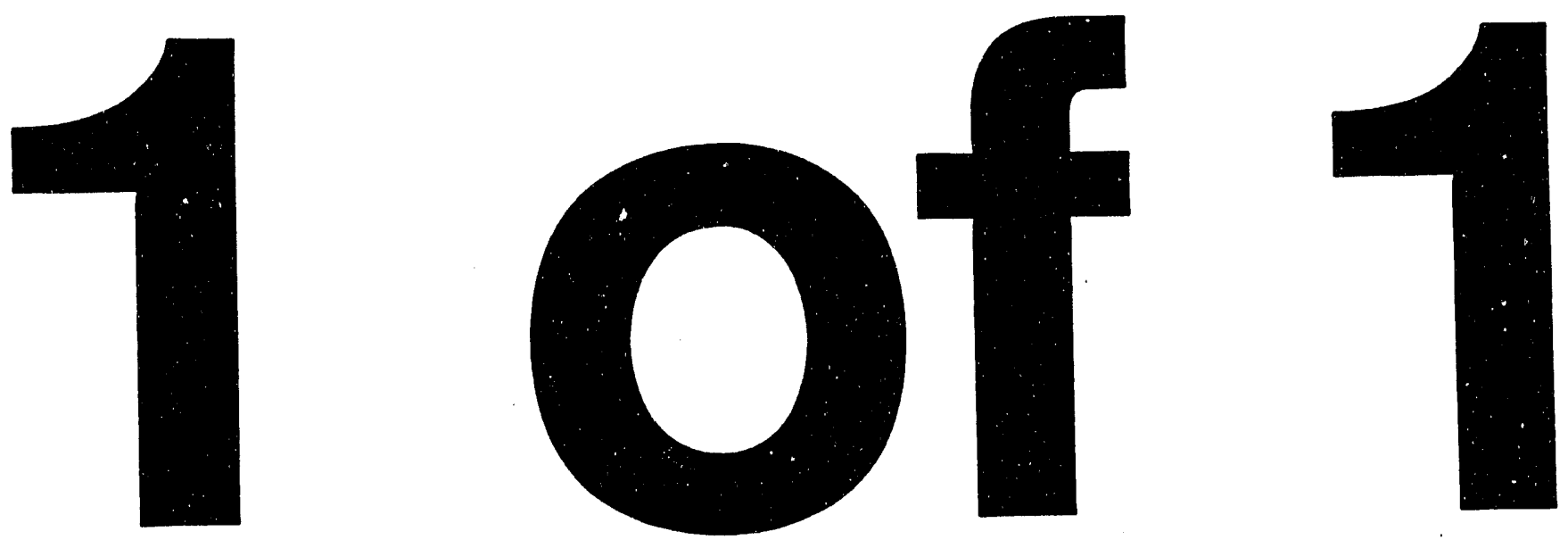

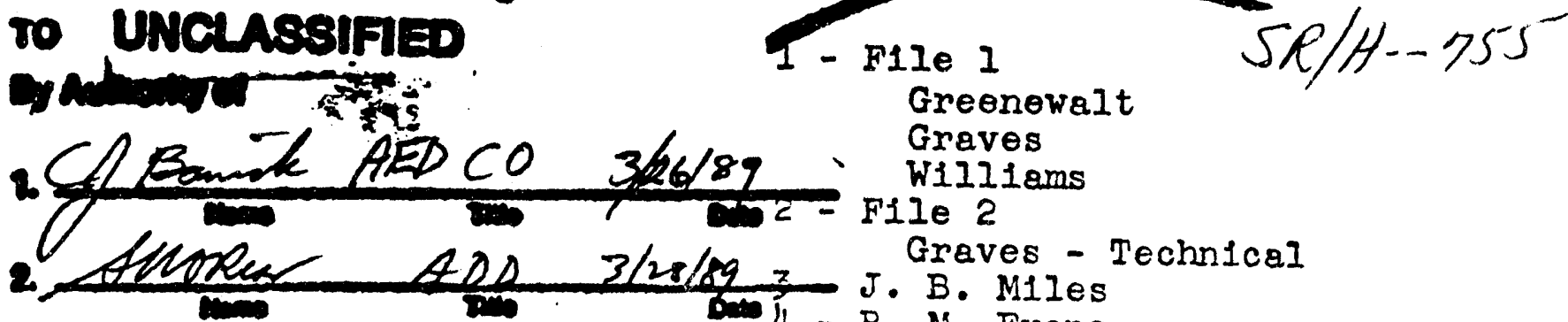

DOEs not CONTAN UNCLASSIFIED CORITROLLEO NUCLEAR INFORMATION

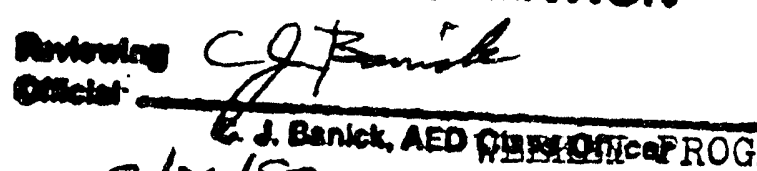

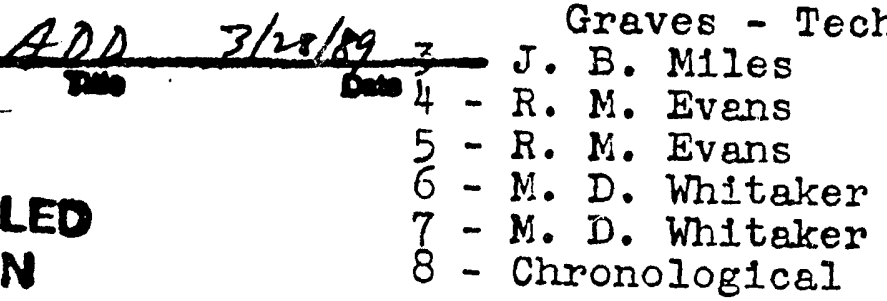

300 and 100 Arees - Hood Worthington

Hood Worthineton

Information on the 300 area test pile that was brought back from Chicago was discussed with members of the Manufacturing Division and written up for formal transmittal to the Design Division. Since the test schedule appeared to require too much time, it was discussed with Weil, with the result that it now appears that the tests can be made at $\varepsilon$ rate of about 110 tests per $24-\mathrm{hr}$. day. A rough estimate calls for 5500 tests yer pile, or a close 55 days testing. First arranement drawings of this pile were reviewea.

The reasons for deaeration vere revieved with Burns, Coffin, Bridge, ano sloen so that a reasonable specification might be developed for the use of vendors. The specification was revieved. Refrigeretion requirements were discussed with Eurns, eivine our point of vew that tie rrincipal reasor for refrietretion is to decrease the time recuired to male tie first sizabie quertities of preduct. For tils reacor, ro refreetration will be provioed for. the thise ar.e iourt? Elles.

The effects of cishine the pine vere reviewce with Frer, Greerevalt,

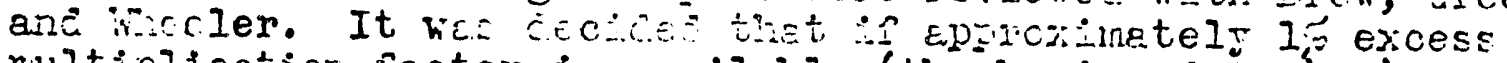
multinliccticr foctor ss availeble (the vasis of CE 107 ), half of

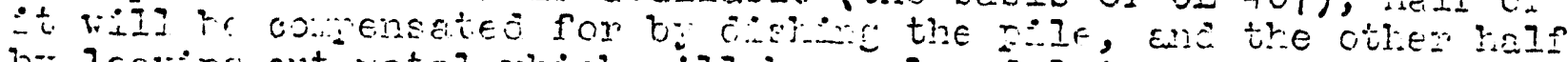

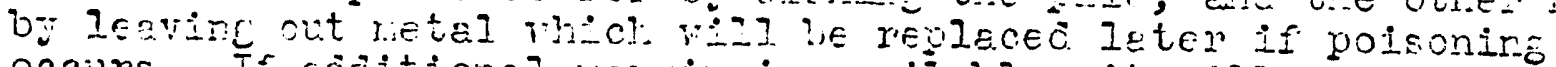

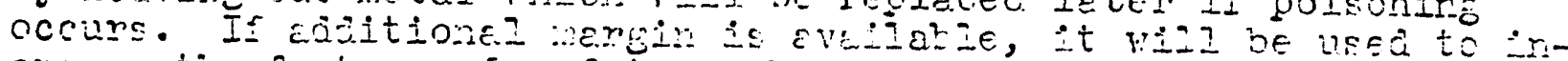

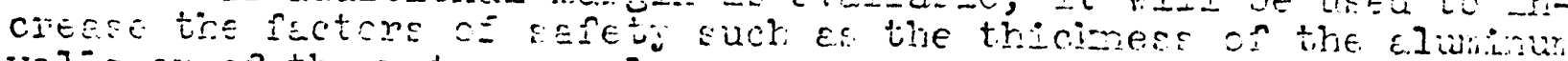

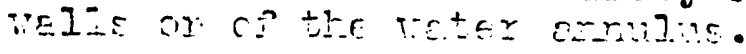

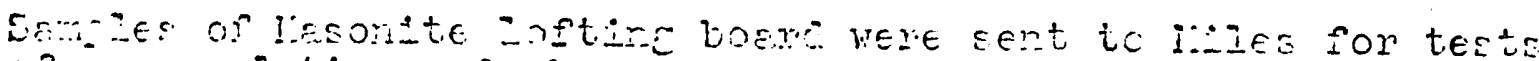

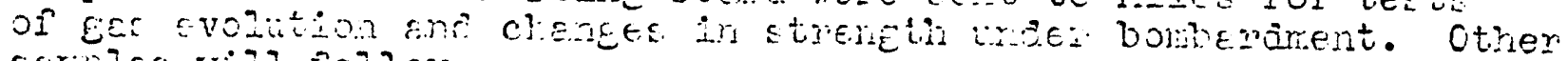

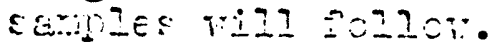

DISTRIBUTION OF THIS DOCUMENT IS UNLIMITED 
K. G. Jones

Extrusion anc liachining

A meeting was held on Nondas to review the extrusion and machinine program. Those present were C. E. Danlels, C.J. Ve1th, C. F. Lange, i.. I. Wherrett, and the writer.

The preheating furnace at $B$ \& $T$ Metels $C o$. does not heve sufficient capacity for our present program and shoula be reiulit before large scale commercial production of site $Y$. metal is begun. Eycessive variation in tempereture betweer the hearth, waIIs and biliets has caused corsioerable difficulty in the past, but. a larger furrace shoula elirinate this problem.

The machinine program at Herring-Hall-Narvin Safe Co. was also discussed. This firm is now ready to meet a schedule of 12 tons per veek and will increase it if necessary. Tool vear is still a problem and various methods of introducing the cooling medium between the tool and the work are being investigated.

The reed for suitable ventilation durine both extrusion and machining was called to Mr. Deniels' attention by the writer. Dr. Iixon of the Chicago Eroup visited both plants ard expressed the opinion that headaches suffered by the operators were probably psychologicel. However, since heavy fumes arise from the extrusion die and lathes auring operation, it is felt that a more thorough investigation should be made. Dr. Gehrmann of the Du Pont liedical Group was contected and a plece of uranium procured for his research work in connection with this problem.

\section{Testing of jeckets}

A memorendum was written to Food Worthington on contempleted tests for jacketed slugs. Three tests are now beine corsidered; a hydrogen test at $300^{\circ} \mathrm{C}$, an $a i r$ test at $500^{\circ} \mathrm{C}$, anc another hydrogen test for the survivors of tie air test. This wiIl probebly be boilea dow to a hidrogen test alone for site X pieces. C. J. Veith of the Inspection Division was cortacted ard will be kept informed on the desired extent of such tests, since they will probably be performed by members of his group.

\section{Straightenine}

Or Vednesday a trip was made to Copperweld Steel Companj's plant ir. Warren, ohio to witness tre straightening of ten extruded bars. The work was dore on a standerd liedart strelglitener and was entirelr successul. The last few inches of three tars snapped off durire the operation due to the fact that the were bedI rinked at this poirt. Hovever, tris has beer called to the attention of $E \varepsilon_{i}$ I Netels Comper $\because$ and such kinks will be renoved by them while tre rod is st1ll hot. 
K. G. Jones (Cont'a.)

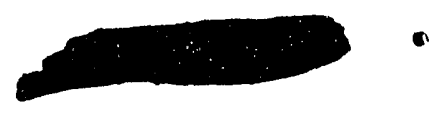

No scaling or spalling off of the oxide coating was noted and in most cases no actual reduction in diameter was made. It is expected that this straightening operation will cut at least 15 minutes from every hour of machining time and increase tool ilfe considerably.

\section{Tubing}

The first attempt at extruding an aluminum tube with unequal ribs was not successful, the eccentricity between the I.D. and O.D. being much too great. Another attempt will be made, but the prevaliling opinion at present is that the section will have to be symmetrical; thet is, with equal ribs. This means that Wolverine Tube Co. will have to draw unequal ribs from a tube with equal ribs or, if this fails, draw equal ribs which will then be broached to the proper size.

\section{Boron Steel}

Control rods for site $X$ containing $1.5 \%$ boron will be made by simonds Saw \& Steel Co. of Lockport, IT. Y. It was at first thought that material for the plie shield would also contain this amount of boron and considerable difficulty was anticipated in procurirg plate with such an analysis. However, it now seems that $a$ boron content as low as $0.25 \%$ w11l be satisfactory and the problem is ruch simplified. Arrangements are being mede with the Simonds Co. to try a small, experimental heat of the low boron steel so that 1 ts working characteristics can be determined. We will then be in a position to approach a larger manufacturer to obtain the arnounts needed in the form of plate.

\section{Aluminum Jackets}

The Aluminum Compeny at New Kensington, Pa. has been given an oraer to jacket 90,000 slugs $1.1 \times 4 "$. The jackets will be applied by pushing the assembly throuch a die and the end closure made by the use of a cap and seam welding. The tolerances on machining of the metal slug, requested by the Aluminum Compang were considered to te excessive since the final size is determired by the die through which the assembly is pushed. The leneti of the slue should not be critical as far as the jacketing operation is concerneo, sirce the aluminum cen must be trimmed before the closure is made. The Aluminum Company is therefore beire asked to chance the tolerances on the print which they submitted to us.

\section{T. D. DreW}

Substantially all the veel has been devoted to stuaying means of distrlbutine metel in the pile and of reducine pressure arop ir. the water tubes for the purpose of securing the meximum power output for a raximuri exit temperature of $65^{\circ} \mathrm{C}$. 
T. B. Drew (Cont'd)

Some attention was given to the problem of heat evolution in the reflector. There appears t be no especial difficulty so far as the top and sides are concerned; maximum temperature in that part is unl1kely to be over $50^{\circ} \mathrm{F}-60^{\circ} \mathrm{F}$ above the temperature of the outer row of tubes. The completion in detail of these calculations is not wholly independent of the problem in the first paragraph.

The lag in operation of a thermostatic control switch was estimated.

W. K. Woods

The correlation of the effect of pitch on pressure drop through spiral channels was issued in memorandum form.

The maximum water rate which might need to be maintained after pile shutdown in order to keep the temperature constant was calculated as a function of the time after shutdown and the results were given to the Nanufacturine Division. No official report discussing the basis for the calculations has been submitted.

Dumny slugs made of wood in the shape of an hour-glass or dogbiscult were tested with air to determine the feasibility of using slugs of this shape in the reflector zone. Although the center of the slugs was "necked down" to less than I inch in diameter, the pressure drop per foot was still $70 \%$ of that expected with cylindrical slugs. The loss was primarily due to the inefficient recovery of kinetic energy in alternate increase and decrease of velocity resulting from changing cross-section; hence it is believed that substantially the same pressure drop might be obtained with only minor "necking down" of the center of the slug.

spiral ship augers have been tested for pressure drop, using water es the flowing medium. When placed inside of a $11 / 2$ inch extra heavy steel pipe $\left(1 . d_{0}=1.500\right.$ inches) with smooth bore, the auger began to spin at a flow rate of about 2.6 Ibs. per second; When pleced Inside of a short length of 3-rib eluminum tubing, no spinning was encountered. It is thought that the absence of spinning in the aluminum tube may be due in part to a slight tendency to wedge between two ribs located $120^{\circ}$ apart, and $a$ test in 4-rib tublne should be made if augers are to be used. In the aluminum tube, the pressure drop per foot of length, including the end connections between the augers, was less than $24 \%$ of that calculated for the smooth slugs. About half of this los was due to the junction between augers, and was relativels independent of the relative orientation of the augers as long as they were separated br "nubbins".

An additional dumm with a reverse spiral is beine made up for test, with the thought that reversine the direction in the center of the dummy slug will eliminete any tendency to spin. A set of "egss" and "doughnuta" is also beine made lip out of wood for testine as a possible alternate to the augers. 


\section{W. K. Woods (Cont'd)}

Present plans call for our taking a two-week vacation beginning Nay 22, so it is hoped that all experimental work w1Il be completed by that time.

C. P. Kidder

Wile final operating conditions for the experimental water corrosion test program at $W$ w1Il be influenced by preceding laboratory tests at Chicago, the following tentative conditions are indicated at the moment.

All vater is to be treated with alum and alkali, settled and filtered. Filtered water is then to be treated in several ways; namely:

A. Complete demineralization, deaeration, $\mathrm{pH}$ adjustment with $\mathrm{CO}_{2}$ (if necessary), and additions of Calgon and $\mathrm{H}_{2} \mathrm{O}_{2}$.

Three tubes w1ll be exposed to the above vater; one to normal conditions of $65^{\circ} \mathrm{C}$ and a velocity of $16.3 \mathrm{ft} . / \mathrm{sec}$; the second to a velocity serles of $16.3-25 \mathrm{ft} . / \mathrm{sec}$. at $65^{\circ} \mathrm{C}$; and the third to a temperature serles of $65-95^{\circ} \mathrm{C}$. at a velocity of $16.3 \mathrm{ft} . / \mathrm{sec}$.

B. Deaeration, $\mathrm{pH}$ adjustment with $\mathrm{H}_{2} \mathrm{SO}_{4}$, additions of Calgon and $\mathrm{H}_{2} \mathrm{O}_{2}$.

Two tubes w111 be exposed to the above water; one to a velocity series of $16.3-25 \mathrm{ft} . / \mathrm{sec}$. at $65^{\circ} \mathrm{C}$; the second to a temperature serles of $65-95^{\circ} \mathrm{C}$ at $a$ nommal velocity of $16.3 \mathrm{ft} . / \mathrm{sec}$.

c. pH adjustment with $\mathrm{H}_{2} \mathrm{SO}_{4}$, additions of $\mathrm{Calgon}$ and $\mathrm{H}_{2} \mathrm{O}_{2}$. One tube will be exposed to the above simply treated water at a normal velocity and temperature of $16.3 \mathrm{ft} . / \mathrm{sec}$. and $65^{\circ} \mathrm{C}$, respectively.

The proposed experinental equipment will be quite flexible so that any of the above treating procedures and additions mey be veriec or omitted, as required.

Based on the above tentative program and two complete analyses or Columbia River water, Chicago has been advisec as to probable chenges in water composition that mat result fror the several purification processes that are to be evaluated.

Equipmeat arrangement drawings of the proposed vater treating facilities, have been completed and submitted to the Permutit company to enable them to prepare piping prints for selected portions of 
C. P. K1dder (Contid.)

the process. In order to facliltate the exchange of detalled design data between the Permutit Compeny and the Du Pont Company, a completion schedule has been prepared for the respective companies. Inftial bullding foundation and architectural drawings are to be completed by June $I$ and equipment foundation drawings by July 1 .

In order to determine the effect of cold treated vater on different construction materials, it is proposed to install spool pleces of selected materials in the several weter lines, ahead of the heaters. The materials under consideration at the moment include rubber-lined steel, stainlese steel, galvenized steel, neoprene-lined steel, Heresite-coated steel, calorized steel, and steel.

\section{Items Requiring Consideration}

Aluminum-cased steel slugs of $W$ design are to be used for the water corrosion experiments and arrangements are being made to have these slugs fabricated. However, the type and design of slug for use et the inlet and outlet of the experimental tubes will have to be selected and arrangements made to have the chosen type fabricated.

W. M. Coons

Experimenta? Water Treatment Project

The list of veter laborators equipment is virtually complete. Iists of photographic and supplementery plant equipment are being prepared.

The laboratory and darlroom lerouts heve been plenned with $C . P$. Kidder and the Engineering Depertment. Photomacrography of split tubes has been discussed vith Nilton Fill, locel vendor.

P.A. Dehien

Ascistance ras Eiven Kadder and Desion in the Icrait of equipment for the Site li corrosion tests. Writing of the operating menuel for these tests vas berun.

\section{Aree - I. Equires}

L. Scuires

f. merorendur ca the onerebilit: of the site $Y$ seperation nlant vas prepered vith Greacer and sclen. Ir a meeting vith representetives

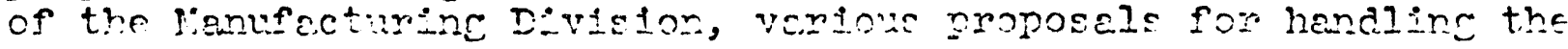




\section{Squires (Cont'd.)}

wastes from the separetion flent at $W$ were discussed and arreemente reached which have been summarized in a memorandum to Graves.

Two dags vere snent at the Netellurglcel Laboratory revieving the current atetus of tie experimentel frosecm. Detalis vere reportec verball: to Greenewc.lt aid were sumerized br Creacer end Acken.

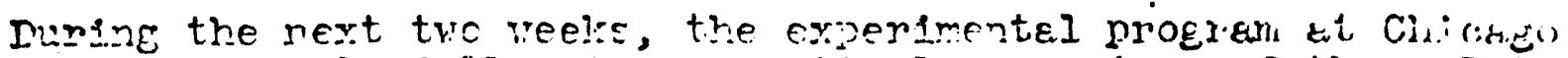

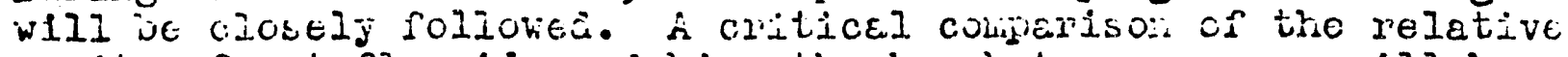

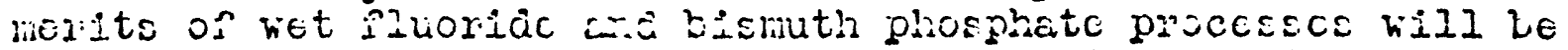

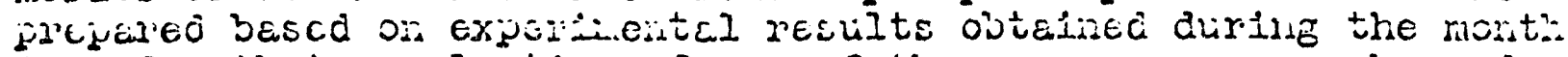
in oldel ihat a sclcctio: of one of these processes can be made on risich to base aesign for W.

1i. F. ficker

Three dejs wore sjent of the site $\mathrm{N}$ design frow the staineipoint of cpeiability with the wct IIuoriât process.

During the lattor part of the week, a trip was rade to Chicago where the following information was obteiried:

iret. Fluoride rrocese Ievelopment

1. It has been ajjaitin for sone tine that a product yiela lose of 10 to $15 \pi$ jel decortemination cycle is encolisieled in the

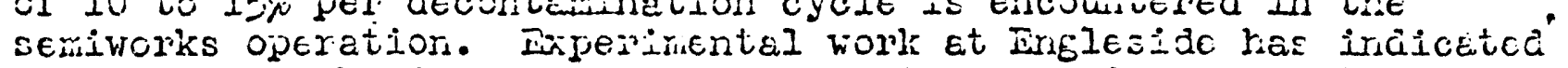
thet this ma ze due ir. Ierge ricasure to cxcessive concentrations of zirconiuri in the decortamiration cacle ceusire incomilete

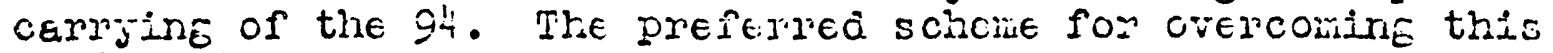
Cifificulty is:

(c) to use water rather thar FF-ITiOs solutilia for vashine the gloduct calie irow the extraction creie in order to periult reavvel ô FF froli tile caite;

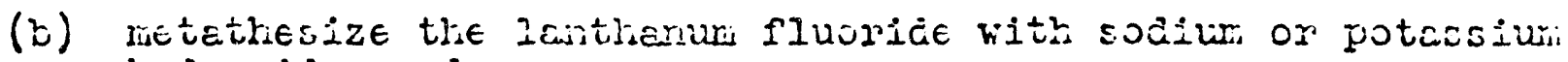
redoxicte; Enid

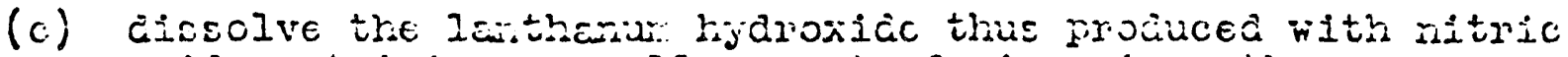

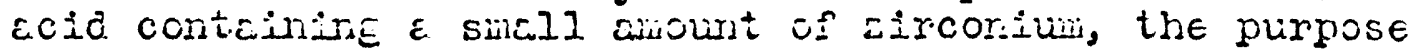
of the zircoriun beire to comizex ars exell enourt of alliali fluolide lest in tre célie.

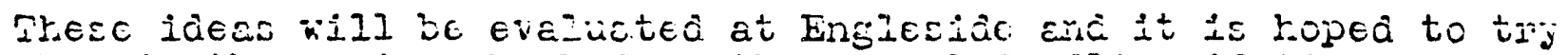
ther ir tie semi-roris before the jure i éeadlinc if tine periute. 
Ni. F. Acken (Cont'd)

2. It is hoped that the reduction in the amount of zirconium used to dissolve the product cake from the extraction cycle will periilt the use of potassium dichromate rather than persulfate for the oxidizing agent in the decontamination cycle.

3. Suitr's group indicated a preference for sodium arsenite as the reducine agent for both the oxidation and reduction cjcles. Another program which is being given lower priority than the precedine points is to Imorove the efficiency of fission product removal bs carrying out a preliminary precipitation with zirconium and cerium phosphates ard bariur sulfate. Arother proposal to be tried at some future time is the use of zirconyl sulfate or hyaroxide rather then the nitrate. Thereafter airconium is required in the process.

\section{E1smuth Thosphate Process}

1. Three bismuth phosphate runs comprising one extraction and one decontamination cycle each have been completed in the semiworks. flthough operation was smooth, the overall decontamination factor for the extraction in one decontamination cycle was only 100 as compared with the expected value of 500 to 2000 . Investigations are now in progress by sutton's group to determine the reason for this serious difficulty. Since the semiworks runs were made with only 5\% active nitrate and the remainder inactive materia.1, Greager has suggested that the fallure to obtain the expected decontamination may be due to beta and gamma activity emanatirif from the $U X-1$ and $U X-2$ which is present in the so-called "deaa" material. Accordingly a semlworks run is planned using notring but the inactive nitrate in order to evaluate the effect of beta and sarma radiation from this source. Other process variables are being Investigated by Sutton's group with the thought that the juight also be a contributing factor to the semiworks difflculties.

2. Filtration of bismuti phosphate does not appear to be very hopeful at the moinent due to bilnding of the filter medium.

3. Small scale rur is in progress using active nitrate mixed with inactive isotopes of the fission elements in order to approximete the concentrations of the fission elerients to be expected at $W$.

4. CorjeII's group have completed an investigetion ol the principal radioactive fission elements present in the irismuth phosphate precipitate obtained at the erid of the first, second, and trird precipitations. The results indicate trat zirconius, collubilu, ans the rare earths are responsible for most of the fissior activity left in the product $\varepsilon$ t the er.d of one decontanina-

- tior cycie. The decortamination factor in the firet decontaniration cycie was poorest for bariuin, columbiur; and ruthenium. 
N. F. Acken (Cont'd)

Equipment Washing

Experlments are st1ll in progress by Smith's group on the removal of flssion activity from equipment suifaces by washing. The results thus far indicate that water washing is sufficient to remove the adsorbed activity. The use of acids for washing is more effective but 1 is is stil an open question whether effective washing of equipment at $W$ can be affected by washing with anj medium. Experimental work at Chicago will be continued.

James A. Collins

The corrosiveness of varlous oxidizing treatments proposed by $J$. Balthis and $S$. Thompson of the Metallurgical Laboratory for the bisnuth phosphate extraction process has been evaluated. These tests indicate that in order to carry out the oxidation step with only dichromium at $70^{\circ} \mathrm{C}$, the concentration should not be above .01 M. However, in combination with. $002 \mathrm{M}$ ceric ion or .05 ferric ion, dichromium as strong as $.02 \mathrm{M}$ maj be used. In fact these latter two combinations are less corrosive than the stralght dichromate treatment. A third alternate which is satisfactory corrosion-wise is a room temperature oxidation using silver and persulfate. These results have been transmitted to $J$. Balthis and $S$. Thompson and wlll be discussed next week in Chicago. It is felt that on the basis of these data, an oxidizing procedure can be worked out which is satisfactory from the viewpolnt of both oxidation and corrosion.

Consideration is being given to the effect on corrosion of process equipment from using zirconyl sulfate as an alternate for zirconyl nitrate as a complexing agent for the fluoride extraction process, and tests are being started to evaluate this point.

The tests carried out in response to the request of $W$. Kirst to evaluate moisture loss vs. time and temperature for standard concrete and a special concrete containing barytes and hajdite have been completed. The special concrete was observed to lose molsture more rapidly than the standard at 25,50 and $100^{\circ} \mathrm{C}$. However, the special concrete had a higher original moisture content and at the end of each test retalned more masture than the standard.

The effect on corrosion of usirs $70 \%$ nitric acid rather than $60 \%$ nitric acid in the metal solution step vould be vers slight. Data developed sometime ago by the Experimental station showed that boliling 70\% nitric acio attacks 18-8-S-Cb at $\varepsilon$ rate which is about $50 ;$ greater than for boiling E0\% ritric acid. Inasmuch as we are usine 25-12-S-Cb, which is more resistart than 18-8-S-Cb, and leboratory corrosion tests indicate a rate of approximately .0005 with $E O \%$ acid, ve vould not expect anj corrosion difficulties to arise through the use of $70 \%$ acid. 
James A. Collins (Contid.)

Design date were recelved from Dr. C. Tucker of the Eloctrochemlcals Department covering their recommendations for equipment to handle, unload, and to store Albone ( 100 volume $\mathrm{H}_{2} \mathrm{O}_{2}$ ).

Samples of acld brick have been recleved from two suppliers which they propose for use in the fume disposal stacks for Hanford. In response to a request from Design Division, tests are being carried out at the Experimental Station to evaluate these materials.

We were advised by $W$. $Q$. Smlth that equipment will be avallable to W. M. Garrison to carry out dielectric strength measurements on samples of electrical insulation exposed to sensitivity. SuEgestions pertaining to testing procedures and materials to test were forwarded in a memorandum to $W$. Q. Smith.

0. H. Greager

Site $X$ flowsheets and prints were reviewed for operability with Squires and Acken. Comments and suggestions for minor elterations in quipment have been incorporated in a memorandum from Squires to Graves.

The latter part of the week was spent at Chicago. Recent semiworks runs on the phosphate method were discussed, and part1cularly the possible factors contributing to the low degree of decontamination obtained in runs to date. Attention was called to possible complications from the large proportions of inactive nitrate used, and this point is being checked by a separate run on inactive nitrate alone.

Recent results on adsorption have been more encouraging. Silica gel is being investigated in a batch-wise process which shows promise of overcoming the very slow flow rates characteristic of column operation. Such a process offers $\varepsilon$ possible means of extracting 94 from uraniun vith a 50-fold reduction in fission products, after which one of the precipitation methods vould be required for decontamination. Extraction by means of silica gel offers a possible advantage in that a large percentage of the fission products can be concentrated in a convenient form for hanalinc, in case the use of such products for nilitary purposes becomes of interest.

Elution of IR-I resin with a $\mathrm{H}_{2} \mathrm{SO}_{4} / \mathrm{Ne}_{2} \mathrm{SO}_{4}$ mixture in place of nitric ecid has overcone the stability dificulties with this edsorbent, and rork is continuine or specific adsorbents for sutsequent use in decontaminetine such a syster.

F. S. Chembere

Dissolver Design 


\section{F. S. Chambers (Cont'd.)}

Results obtained at the Metallurgical Laboratory from the dissolving of 6 site $X$ slugs with a 5.8 ratio of $60 \%$ nitric indicate the average dissolving time will be 16 hours and the maximum approximately 18 , with a peak rate of about $25 \%$ of the original we ight of metal per hour. By extrapolating these data, it has been celculated that the average aissolvine time for a $W$ slue should be 20 hours and the maximura 23 hours with $a$ pear rate of $20 \%$ per hour. The above solution times which are based on dissolvine sinele sluge may well be lower then the time required for a pile containine several hundred pieces. fry discrepeincy from this source, however, should not irteriere materially with the plerit operation since the dissolving tire car be cecreased by eithel increasing the acid streneth to $70 \%$ or by allowins a hecil of widissolved metal to remain in the dissolver. This woula be picked up byr the next batch.

\section{Coatine Solution}

Experiments at the lietallurejcel Lejonatory have shom that the alur Inum coetire ce ve dissolved rapidly in nitric acid containing $3 \%$ mercury as mercuric nitrate on the besis of the veigit of aluminum. 4.4 nol Fo, jer mol of alumiruri were found to be sufficient to give a firal solution with enough acidity to prevent precipitation of aluninur. The results irdicete that jo niriutes

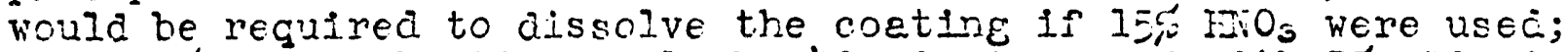

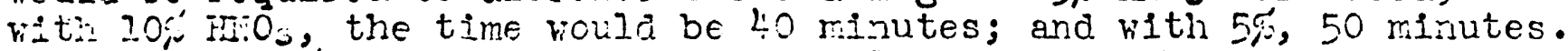
Iess then $0.1 \%$ of thie ureniur: is cissolved duririe this operation.

\section{Fadioactive off-Gases}

The probler of tre dispcscl of the radioactive E-day iodine liberatea curing the solution of retal at hi vas discussed with cole end Church at the lietallurejcal Laboratory. The present maximu: clound level or:centretion for cont nued exposure to this cas lies veen set at $2.5 \times 10-1 \equiv$ curies $\mathrm{E} \in \mathrm{r}$ co. To reach this dilution ritil an IE-hour solution peris anci a $200-i t$. stack, a 4 mile rew hour wind rould be requerea. ilzowing the retal fror the pile to deceij anobrier li dajs, hovever, would reduce the required

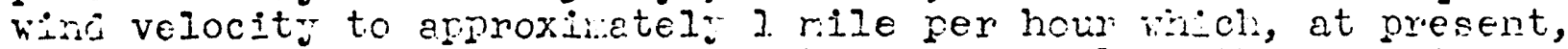
erpears to be satisfectory for ell but unusuel veether conditiors, er fecially since the preveilfne winas should blor the stack gases over unuseci portions of tile site.

Church, the lietellureicel Laboratory's meteoviogist is at present

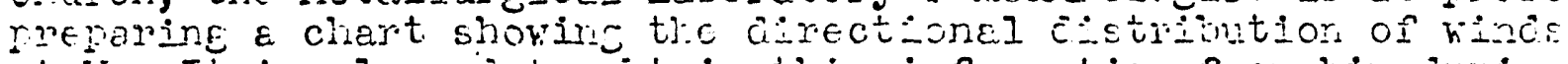

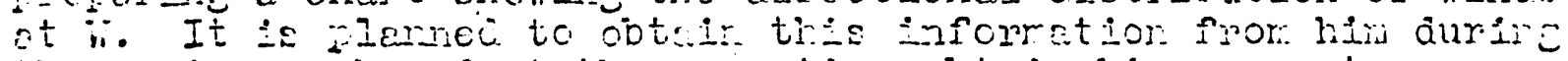
the conjue veel and et the sare tine obteir liss corsents on

the resert locetion of the seperetire arce siachis. 


\section{Phys1cs, Instmumentation and 100 Area Control - D. F. Bebcock}

\section{F. Babcock}

Greenewalt has suggested that sufficlent steam pump capac1ty be provided so that in case the electric pumps fall the water feed to the pile vill stili remain at a level that vill prevent boling of the water within the pile. This will amount to something like $50 \%$ of the standard vater flow and would require something like $20 \%$ of the total power (exact figures cannot be given until vater inlet and exit temperatures and degree of bowing have 1 en set). On this basis it is nrobable that there will be no rieed for the safety rods to act facter then in $2-3$ seconds.

A memorandum was issued vith Wheeler or the subject of possible p1le catastrophes (Nias 13, 1943).

Calculations were made on schedules for dischargin metal from a pile. Niy memorandum of March 29 which was computed for a plle with an effective radius of 12.024 feet and a true radius of II feet, by a happenstance, gives the true concentration levels for our present water cooled pile having an efiective radius of 16.8 feet and a true radius of 15.35 feet.

C. W. J. Wende

Radiation hazards from metal storage basins and from waste disposal systems at Site- $W$ have been discussed in a memorandum to I. Squires on $\mathrm{Ner}$ 14, 1943. The celculations take into account both direct radiation and sky shine, end graphs for the rapid computation of these effects are appended to the memorandum. Several discussions on the shielding of sampline devices wert held with members of the operating Division, and calculations were provided on a number of provisionel desiens. Friedman's equations for the escane of game radiation through annuler channels (letter, Allis on to CreeneweIt, $5 / 8 / 43)$ were derived to rake his methods available for our further use.

sttention durine the nert weel vill ve Eiver to problems of irduced activit: ir: dummies and control rods.

Ionn S. Ineclen

Sethods for alterine the distribution of heat production lr the vater cosled plle heve beer under consideretic: for some tive crid

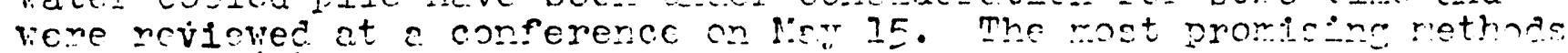

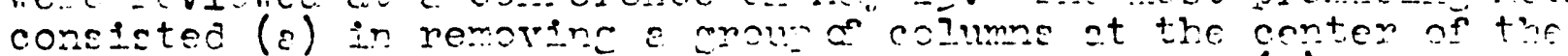

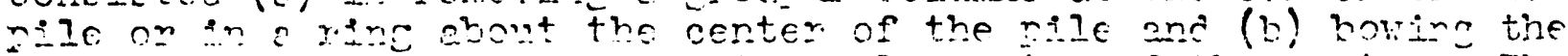

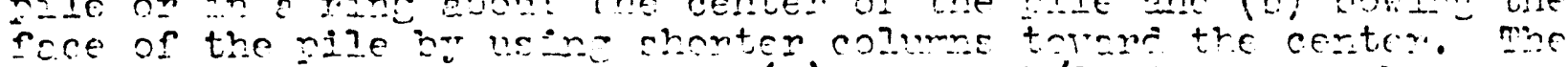

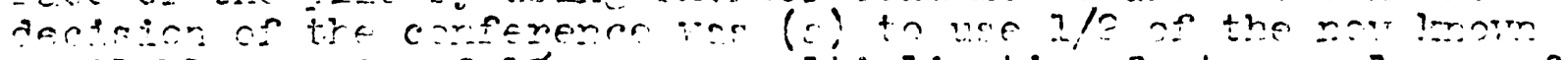

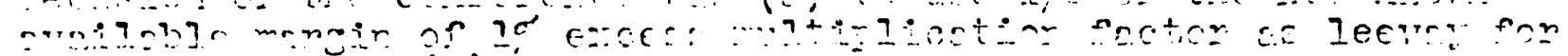
bovine the nole, (h) to remve onter of colums ot the center or 


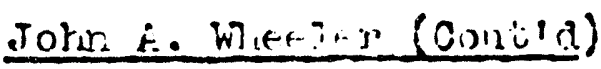

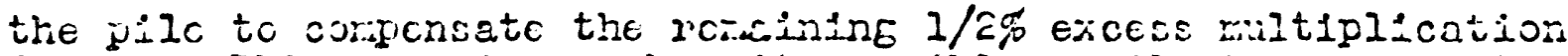
factor. Mris procecune maic -i possiblc easilj to compersatc

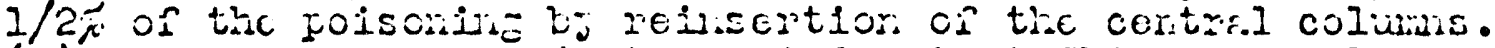
(c) If the crijerinert just cairied out at Chlcagi saall prove on enclysis to deronetrate the exictcince of $2 \%$ e:ces zultiplication

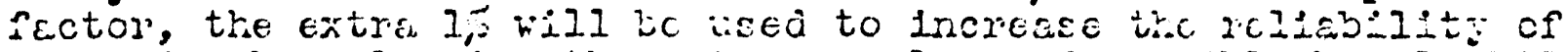
operetion bj enlaleine the weter andulus and possibly by slienti ircreasins the thickness of the aluminuri.

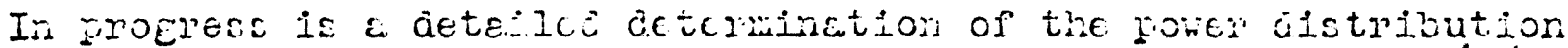
Ir the case of bowire of the File sufficient to cupensate $1 / 2 \%$ excess $k$, with and vithout reavval of central tibes to lower $h$ another $1 / 2 \%$.

I. Way

\section{Coritrol}

f calculation of the lifetire of a neutron in the W pile with figOT Graphite was made frora the best available constents and found to be $1.2 \hat{c} \times 10^{-3}$ sec. Tris, toether with the latest values for cielayed neutron percentaés, Eives for the lelation betwecn pile period, $T$, end $\mathrm{K}-\mathrm{I}$.

$$
r-1=3 \times 10^{-5}\left[\frac{40.1}{r}+\frac{269}{r+3.57}+\frac{761}{r+10.1}+\frac{2175}{r+34.5}+\frac{69 z}{r+85}\right]
$$

Application of this expressios to the probleis of findine the power cutput at a time, $T$, after the insertion of the control roas, cssumine that these decrease Is by .02 gives the Iollowirie results:

$\frac{\text { Fower outjut } 0.2 \text { sec. arter insertion of rods }}{\text { steadi power output }}=.27 \overline{5}$

Fower output 1 sec. after insertion of rojs $=.264$ Steads power output

\section{IicIivin}

Sorie data were collected on poseible ajounts of radiocctivity of tre eas liberated in tric bioloejcal shield which might enter the he Iiun. sjster..

The heliuii jor will be firished ard e eenclel formation of the control rod ezpressicres outlires as soor as jossitle.

\section{S. Iiviniansis:}

liost of the weer wes eccuipiea rith ettine up to zate on tie

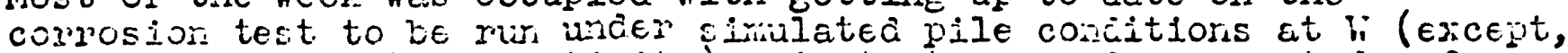
of course, fo: 1rtense activity). f. start wes luaste or a study of the best tjpe of storage tank for the demiremalized, deaerateo water for tie pile. 
Clinton - W. E. Kirst

\section{W. E. KIrst}

S1te X Ranual

Further material has been added. It has been decided to issue this manual by sections in separate binders. The first issue will consist of 30 copies which will satisfy the present circulation and leave several spare coples. Beginning the week of May 16, sections w1ll be 1ssued as fast as they are completed,

\section{DISCLAIMER}

This report was prepared as an account of work sponsored by an agency of the United States Government. Neither the United States Government nor any agency thereof, nor any of their employees, makes any warranty, express or implied, or assumes any legal liability or responsibility for the accuracy, completeness, or usefulness of any information, apparatus, product, or process disclosed, or represents that its use would not infringe privately owned rights. Reference herein to any specific commercial product, process, or service by trade name, trademark, manufacturer, or otherwise does not necessarily constitute or imply its endorsement, recommendation, or favoring by the United States Government or any agency thereof. The views and opinions of authors expressed herein do not necessarily state or reflect those of the United States Government or any agency thereof. 
Ex.1104*

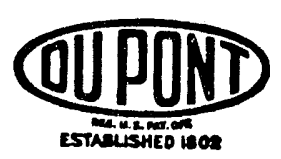

E. I. du Pont de Nemours \& Company inconmonutes

WILMINGTON, DELAWARE

EXPLOSIVES DEPARTMENT

TMX

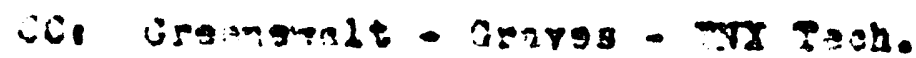

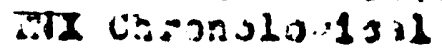

A. S. Repnto-leentry

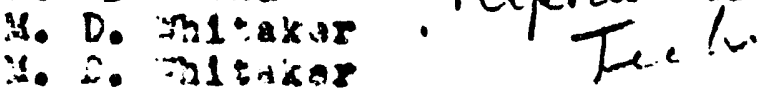

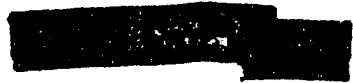

$20517,1,43$

H)

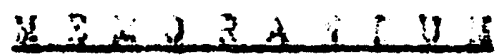

TO. HO:D ORTUI:ICTON

?.7348 D. B. 27213

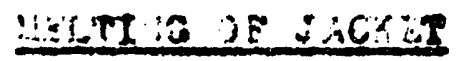

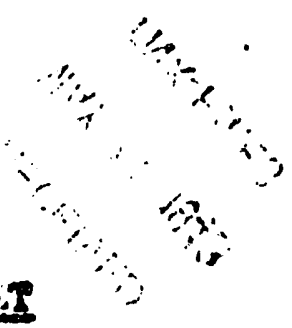

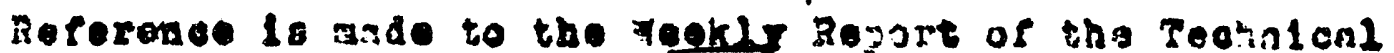

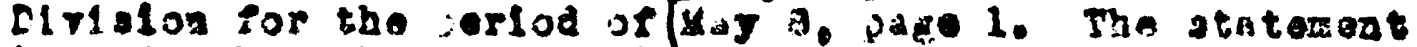

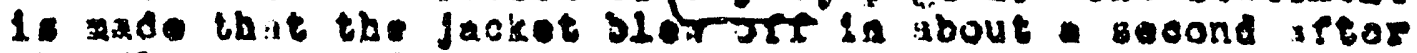

the s10w stospod. The etaterant ande hore rsa that

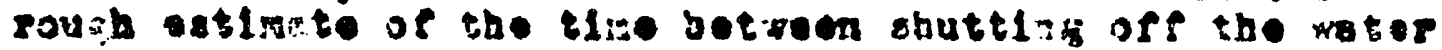
and the swor was thirty soosnde.

JB:X/11

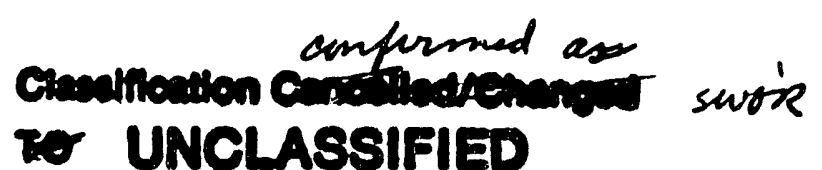

Dy Authority of

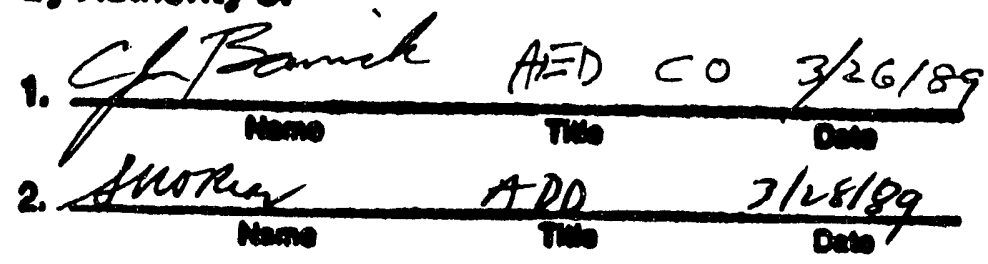

$$
\begin{aligned}
& \text { DOES NOT CONTAM } \\
& \text { UNCLASSIFIED CORTROLUD } \\
& \text { NUCLEAR INFORMATION }
\end{aligned}
$$

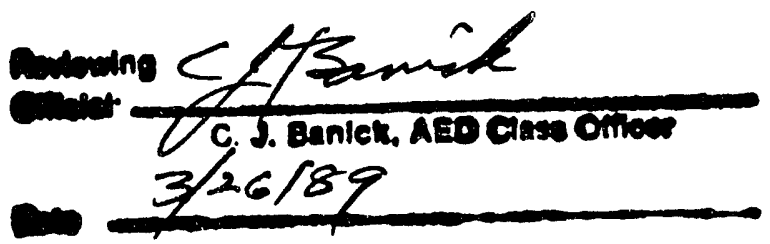



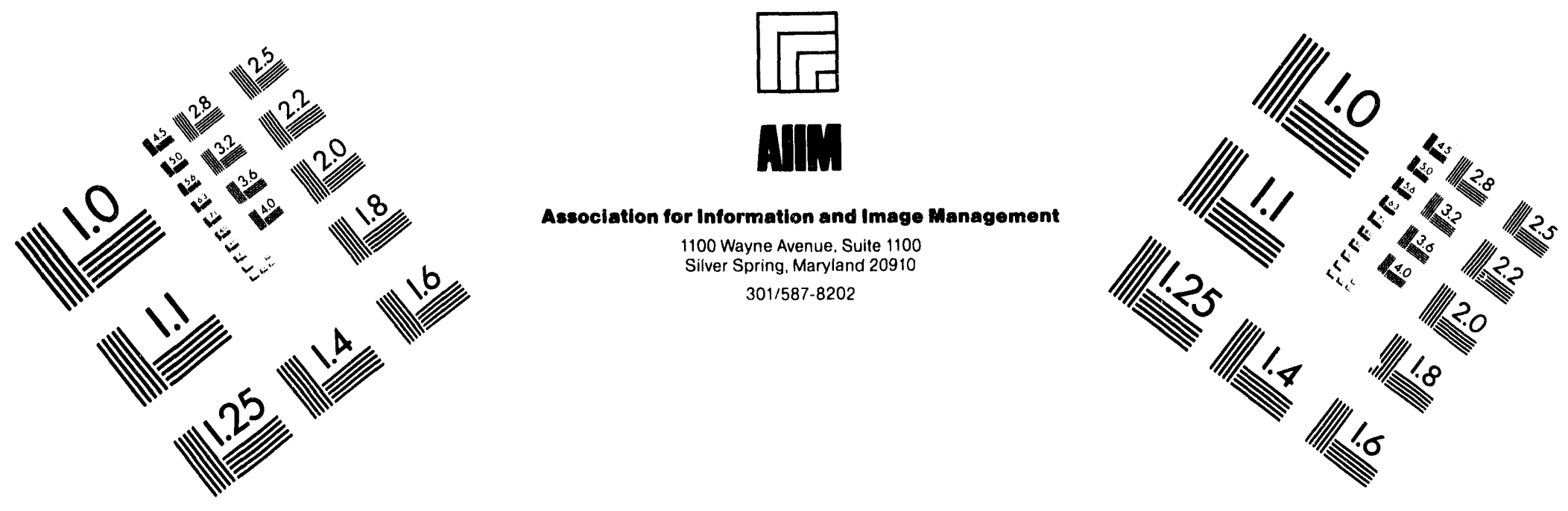

\section{Centimeter}

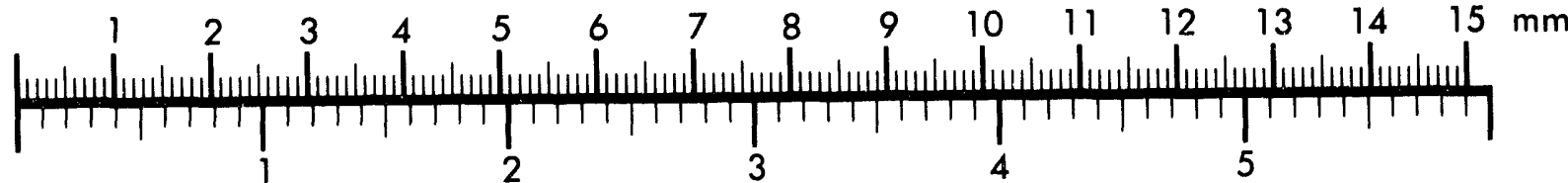

Inches
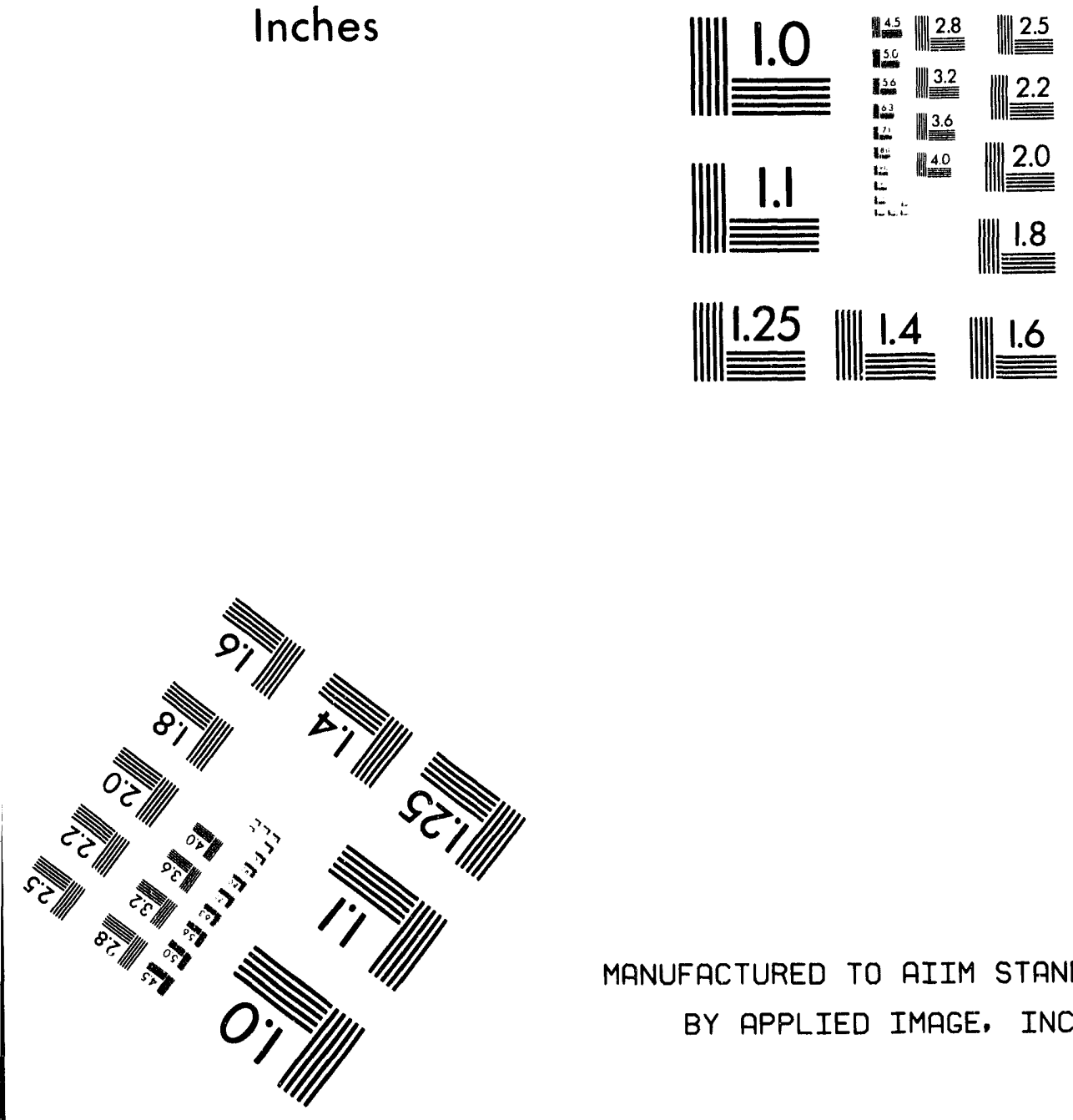

MANUFACTURED TO AIIM STANDARDS

BY APPLIED IMAGE. INC.

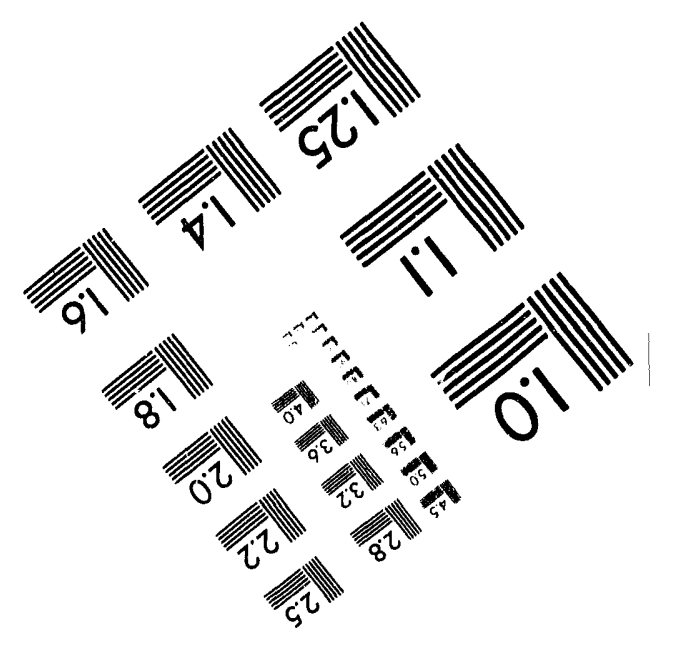




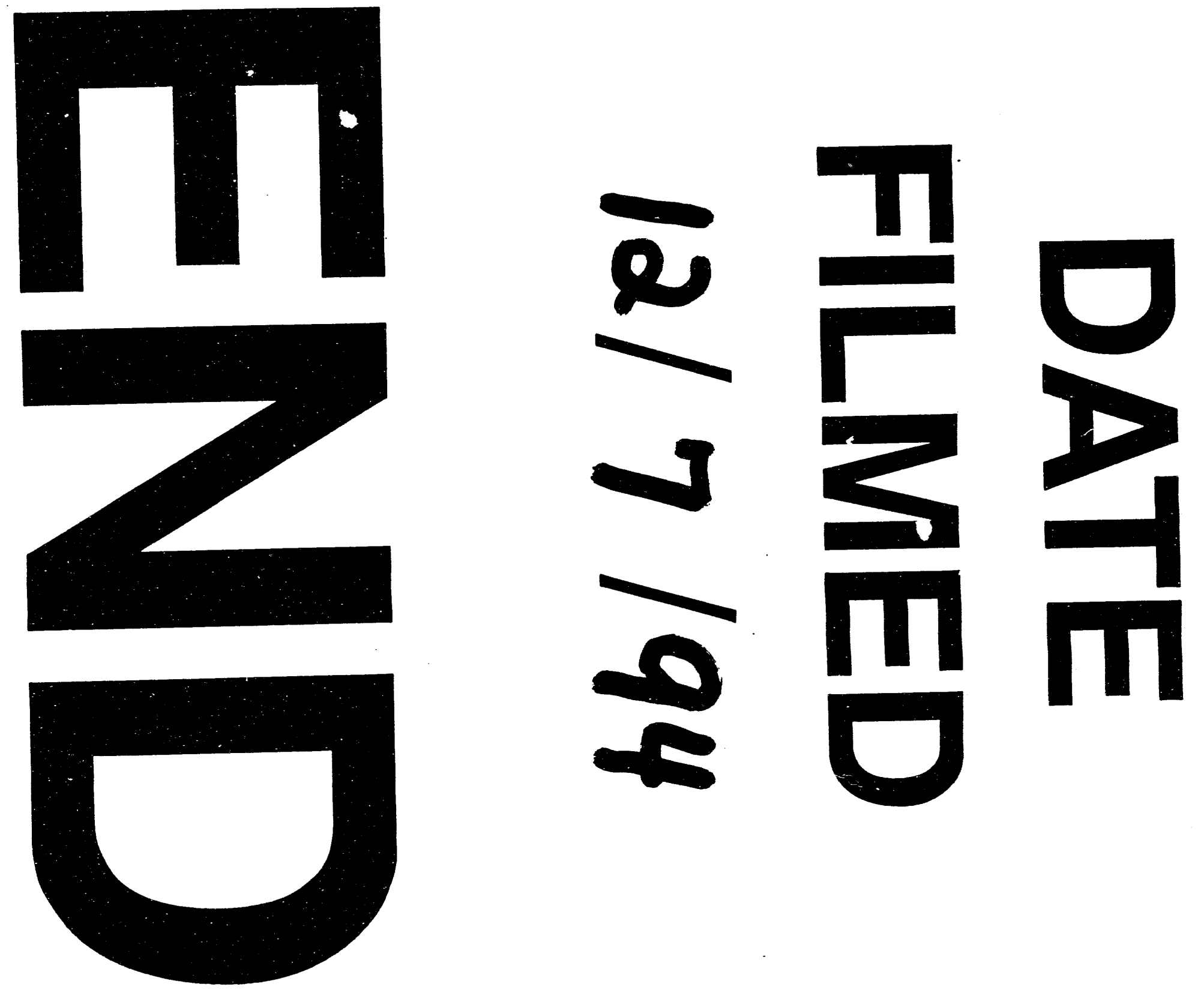